\title{
POST-ISLAMISME: MEMAHAMI AKSI POLITIK ISLAM KONTEMPORER
}

\author{
Syahrir Karim \\ UIN Alauddin Makassar \\ Email: syahrir.karim@uin-alauddin.ac.id
}

\begin{abstract}
Abstrak
Post-Islamisme merupakan fenomena politik Islam yang dinamis sehingga tersebar dengan beragam karakter. Kelompok-kelompok yang sebelumnya berbeda secara ideologis mencoba melebur dalam satu gerakan yang sama dan berusaha berkompromi atau bahkan melawan. Kelompok-kelompok atau ormas-ormas Islam yang cenderung berkompromi dengan negara merupakan cara mereka untuk terus bisa eksis dalam realitas politik. Meskipun sebenarnya sebagian dari mereka tetap tidak meninggalkan tujuan atau ideologi organisasi secara penuh. Hal ini tidak lain adalah untuk tetap menjaga simpati masyarakat dan pada sisi yang lain tetap eksis dalam dinamika politik bernegara. Fenomena ini sejalan dengan beberapa ciri utama post-Islamisme, antara lain cenderung pragmatis, cenderung berkompromi dengan negara tanpa sepenuhnya meninggalkan ciri khas ideologis mereka, serta mereka cenderung lebih realistis melihat keadaan. Hal ini terlihat bahwa post-Islamisme cenderung kurang begitu sepaham dengan isu-isu sekularisme dan pada sisi yang lain mereka juga menolak penerapan-penerapan syariat yang kelihatan kaku termasuk platform ideologiskeagamaan dalam penerapannya di beberapa tempat. Secara umum, ciri-ciri postIslamisme cenderung sama, seperti kompromi dengan kenyataan politik, cenderung pragmatis dalam menjalankan program pemerintah dan sikap toleran terhadap kelompok-kelompok yang dianggap berbeda dengan mereka.
\end{abstract}

\section{Kata Kunci: \\ Post-Islamisme, Aktivisme Politik, Ideologi, Politik Islam}

\begin{abstract}
Post-Islamism is a dynamic Islamic political phenomenon that spreads with various characters. Previously ideologically different groups tried to merge into the same movement and tried to compromise or even fight. Islamic groups or mass organizations that tend to compromise with the state are their way to continue to exist in political reality. Although actually some of them still do not abandon the goals or ideology of the organization totally. This is purely to maintain public sympathy and on the other hand, to exist in the dynamics of state politics. This phenomenon is in line with several main characteristics of post-Islamism, among others, they tend to be pragmatic, tend to compromise with the state without completely abandoning their ideological characteristics, and they tend to be more realistic in seeing the situation. It can be seen that post-Islamism tends to be less in tune with issues of secularism and on the other hand they also reject the application of Sharia law which looks rigid, including ideological-religious platforms in its application in several places. In general, the
\end{abstract}


characteristics of post-Islamism tend to be the same, such as compromise with political realities, pragmatic tendencies in carrying out government programs, and a tolerant attitude towards groups that are considered different with them.

\section{Keywords:}

Post Islamism, Political Activism, Ideology, Political Islam

\section{Pendahuluan}

Islam subtansial dan Islam formalistik kembali dibicarakan setelah sebelumnya ketika Cak Nur mengeluarkan jargon 'Islam Yes-Partai Islam No' yang pernah menjadi isu dan perdebatan pada masanya. Perdebatan itu terjadi pada wilayah pemaknaan dan pada tingkat implementasi isu dan simbol. Perwujudan Islam secara simbolik ataupun isu oleh kalangan Islam politik itu penting dan menjadi satu keharusan. Sebaliknya, bagi kalangan Islam substantif menentang kehadiran partai Islam dan simbolisasi syariat oleh negara. Kalangan Islam substantif (biasanya disebut liberal) menolak seluruh bentuk perjuangan yang hendak memformalkan Islam dalam politik. Di lain pihak, Islam formalistik ingin memperjuangkan formalisasi atau simbolisasi syariat. Bagi mereka, Islam tidak mengenal pemisahan dalam bentuk apapun termasuk antara agama dan negara. Mereka yang hendak memisahkan antara agama dan negara disebut sekuler. Fenomena ini terlihat lebih jelas di era reformasi yang mendatangkan kesan liberalisasi politik di Indonesia sampai hari ini.

Banyaknya partai politik di era reformasi merupakan bagian dari wujud liberalisasi politik, termasuk partai-partai yang mempunyai social origin Islam. Agama menjadi simbol-simbol politik terlihat sangat banyak penggunaannya terutama tampak dalam lambang dan azas partai. Fenomena ini secara umum melahirkan anggapan bahwa kekuatan politik Islam kembali lahir. Penilaian ini dianggap wajar karena penduduk Indonesia adalah mayoritas Islam. Fakta bahwa Islam adalah mayoritas pasti mempunyai implikasi politik yang jelas. Kekuatan-kekuatan politik yang ada pasti akan memperebutkan basis massa Islam termasuk partai-partai yang tidak mempunyai basis massa Islam sekalipun.

Sekali lagi bahwa realitas di atas seakan mempertegas bahwa fenomena agama selalu ada dalam sejarah politik khususnya Indonesia. Pada sisi yang lain, bahwa kemudian ada kekhawatiran ketika simbolisasi syariat akan mengancam integrasi dan sekaligus merusak kesucian agama serta kekhawatiran bahwa agama akan dijadikan alat 
kepentingan politik elit tertentu adalah hal yang wajar. Kekhawatiran ini juga berangkat dari realitas politik selama ini khususnya di era reformasi. Berbeda ketika Islam muncul secara formalistik, terlepas dari beberapa fakta negatifnya tetapi setidaknya keberadaan simbol Islam bisa menjadi sistem nilai yang setiap saat bisa menjadi 'rem' atau pengingat ketika keluar dari koridor agama. Dengan adanya simbol tersebut membuat aktor politik akan selalu merasa terawasi oleh masyarakat luas karena pada mereka melengket garis ideologi yang jelas.

Akhirnya, dengan dasar argumentasi masing-masing bahwa perdebatan antara Islam substantif dan Islam formalistik akan terus menjadi perdebatan panjang dan akan terus ada, tinggal bagaimana umat Islam bisa menjadikan perbedaan itu sebagai satu hal yang wajar. Fenomena ini akan terus bergulir dengan beragam warna dan karakternya masing-masing. Hal ini tidak terlepas dari jargon "al-Islam din wa dawlah", bahwa Islam adalah agama dan negara sebagai cerminan bahwa Islam tidak pernah lepas dari politik. Dengan kata lain, Islam tampak sebagai kerangka atau basis ideologi politik yang mengejawantah dalam kekuasaan politik. Dalam konteks ini, kelihatan bahwa Islam berada dalam dua bentuk, yakni; Islam sebagai sistem nilai yang sarat dengan nilai-nilai transendental dan Islam dimaknai sebagai realitas sejarah. Sebagai sistem nilai, Islam harus kembali pada ajaran Nabi yang berlandaskan Al-Qur'an dan Sunnah. Selanjutnya kalau Islam dimaknai sebagai realitas sejarah, maka basisnya adalah kebudayaan dan peradaban Islam. Kedua perwujudan ini kemudian mestinya menjadi kerangka logis ketika berbicara Islam dan politik.

Hal di atas menjadi landasan baik secara simbolik maupun teologis bahwa Islam akan terus ada dalam realitas politik negara atau kekuasaan. Ragam corak dan karakternya merupakan salah satu wujud bagaimana mereka tetap bisa eksis dalam realitas politik. Respon politik umat Islam akan terus menjadi sorotan publik yang sering mengaitkannya dengan hal-hal yang politis ideologis. Sebutlah misalnya bagaimana fenomena Islamisme sampai pada post-Islamisme. Islamisme merespon relaitas politik secara berbeda dengan post-Islamisme. Perbedaan secara ideologis sebenarnya tidak begitu jauh, akan tetapi dalam hal merespon realitas politik di sini kemudian ada kecenderungan berbeda. Berkembangnya situasi politik atau setidaknya "liberalisasi" politik pasca reformasi membuat kaum Islamis "dipaksa" untuk berkompromi dengan realistas politik yang ada sehingga otomatis muncul semacam 
keharusan untuk merubah pola gerakan politik Islam. Post-Islamisme pun muncul sebagai alternatif gerakan politik untuk tetap bisa survive di tengah gempuran politik yang semakin modern.

\section{Islam dan Islamisme}

Di antara cara untuk memahami fenomena Islam saat ini adalah dengan melihat Islam sebagai sistem nilai dan ajaran sekaligus sebagai sebuah realitas sosial. ${ }^{1}$ Sebagai sistem nilai dan ajaran, Islam jelas bersifat transenden dan Ilahiah. Selanjutnya, sebagai realitas sosial, Islam adalah sebuah fenomena peradaban dan kultur dalam kehidupan sosial manusia. Dalam pemaknaan Islam dan realitas sosial tidak hanya penuh dengan doktrin yang bersifat kontekstual dan universal, akan tetapi nilai-nilai Islam terinternalisasi dalam institusi-institusi sosial. Dengan kata lain, terlepas dari bagaimana wujud konkritnya, Islam adalah agama yang amat berkepentingan untuk "membumikan" pesan-pesan moralnya dalam konteks kehidupan kolektif manusia. ${ }^{2}$ Dari sinilah kelihatan telah terjadi sebuah evolusi secara sistematis, yakni berangkat dari aqidah lalu kemudian terejawantah menjadi syariat, dari sebuah keyakinan menjadi sebuah sistem sosial kemasyarakatan dan bernegara.

Dalam realitas politik berbangsa dan bernegara, Islam dan politik memiliki wajah yang tidak tunggal. Di antaranya kelompok yang cenderung bekerjasama dengan pemerintah, kelompok cenderung menjadikan Islam hanya sebagai ajaran masyarakat yang tidak perlu disertai keterlibatan politik, serta kelompok yang menolak sama sekali kaitan antara Islam dan politik. Tetapi apapun kecenderungannya, sebagai realitas sejarah, Islam tidak bisa terlepas dari politik. Bagi Nazih Ayyubi, Islam politik merupakan fenomena yang terkait dengan doktrin dan atau gerakan yang meyakini Islam memiliki teori politik dan negara (a theory of politics and the state). ${ }^{3}$ Islam dalam sejarahnya tidak pernah berhenti berpolitik, berawal dari Negara Madinah sampai sekarang adalah realitas tak terbantahkan. Nabi bukan saja sebagai pemimpin agama yang memiliki wewenang spiritual karena statusnya sebagai Rasul, tetapi juga kepala

\footnotetext{
${ }^{1}$ Azyumardi Azra, Pergolakan Politik Islam: dari Fundamentalisme, Modernisme, hingga Post-Modernisme (Jakarta: Paramadina, 1996), h. 89.

${ }^{2}$ Ahmad Syafii Maarif, Islam dan Politik: Teori Belah Bambu Masa Demokrasi Terpimpin (1959-1965) (Jakarta: Gema Insani Press, 1996), h. 138-139.

${ }^{3}$ Noorhaidi Hasan, Islam Politik di Dunia Kontemporer: Konsep, Genealogi dan Teori (Yogyakarta: SUKA Press, 2012), h. 5.
} 
negara yang memiliki kekuasaan yang sifatnya duniawi (secular). Negara Madinah telah menjadi dasar teologis dalam politik Islam. Dengan kata lain bahwa ungkapan tentang Islam atau agama harus lepas dari politik berarti sama saja telah mengingkari sejarahnya sendiri. Sekaligus mengingkari bahwa agama adalah seperangkat sistem sosial yang penuh dengan ajaran moral dalam berbangsa dan bernegara dengan beragam bentuknya. Di sinilah kemudian menjadi titik di mana Islam membangun karakter politik yang dinamis di tempat dan zamannya masing-masing. Wujud Islam dengan wajah politik inilah yang kemudian muncul ragam karakter Islam dalam merespon realias politik. Di sinilah awal munculnya ungkapan kaum Islamis, yakni mereka mengusung Islam secara ideologis dalam kancah politik negara. Islamis sendiri berasal dari penggalan kata Islamis-me sebagai sebuah pemikiran yang menempatkan Islam bukan hanya sebagai sebuah agama tetapi juga sebagai ideologi sosial-politik. Fenomena aktivisme Islam inilah yang sering diidentikkan dengan kaum Islamis. Gerakan kolekif kaum Islamis ini terjadi dihampir semua negara khususnya negara dengan mayoritas penduduknya Muslim seperti Timur Tengah termasuk di Indonesia.

Islamis terkadang mempunyai konotasi yang negatif. Di antara konotasi yang negatif itu misalnya adalah bahwa Islamis termasuk dalam kelompok radikal, sebuah gerakan yang anti demokrasi dan lain-lain. Islamis terkadang dihubung-hubungkan dengan sekelompok orang yang selalu berlawanan dan menentang pemerintah. Faktorfaktor eksternal mulai memberikan kontribusi terhadap kebangkitan Islamisme radikal selama masa kolonialisme di mana hampir semua tanah milik umat Islam berada di bawah kendali kekuatan asing, khususnya negara-negara Barat. Bahkan, beberapa asumsi bermunculan diantaranya adalah bahwa kolonialisme Barat bertanggung jawab terhadap kondisi sulit yang dialami umat Islam di seluruh dunia, seperi terjadinya eksploitasi sumber-sumber daya alam dan ekonomi. Sebagai bagian resistensi mereka terhadap kolonialisme Barat, umat Islam berjihad untuk mengusir kekuatan Barat dari tanah mereka. Hasilnya, ekstrimisme berbasis agama tumbuh dengan subur di negaranegara Islam. Tujuan jihad bagi umat Islam pada masa kolonialisme adalah membebaskan tanah mereka dari hegemoni Barat. ${ }^{4}$ Pola-pola perlawanan inilah kemudian menyebabkan kaum Islamis selalu dicurigai keberadaan dan pergerakannya

${ }^{4}$ Masdar Hilmy, Teologi Perlawanan: Islamisme dan Diskursus di Indonesia Pasca Orde Baru (Yogyakarta: Kanisisus, 2009), h. 69. 
oleh negara sehingga eksistensi mereka terus di bawah tekanan. Kelompok ini dikhawatirkan mempunyai daya militansi yang bisa membajak sistem demokrasi yang kemudian akan melahirkan otoritarianisme dengan wajah baru. Adanya kecurigaan dan tekanan dari negara membuat kaum Islamis cenderung merubah pola gerakannnya ke arah yang lebih bisa diterima oleh negara dan tidak mengundang kecurigaan yang berlebihan. Logika syariat kemudian sedikit bergeser masuk ke logika negara sebagai wujud "kompromi".

Wujud kompromi ini kemudian memberi kesan titik kategorisasi dalam melihat pola Islamisme ini. Islamisme tidak bisa ditempatkan dalam kategori terpisah dalam melihat Muslim yang moderat atau bahkan liberal hanya karena keterlibatan mereka dalam akivisme politik. Bagi Fealy, faktanya bahwa Islamisme adalah rangkaian kesatuan tanpa batas yang membuat batasan antara Islamisme dan "Islam moderat" menjadi kabur. Logikanya adalah bahwa pemikiran kaum Islamis dengan sangat mudah bisa berdampingan dengan Muslim "moderat" dalam masalah tertentu dan mendapatkan gaungnya di kalangan organisasi Islam mainstream seperti Muhammadiyah dan Nahdlatul Ulama (NU). Di luar reputasi mereka sebagai organisasi "moderat", tidak dipungkiri bahwa sebagian dari organisasi ini bersimpati kepada agenda utama kelompok Islamis. Maka menjadi suatu hal yang biasa ketika ada keputusan strategis sebuah organisasi mainstream sejalan atau bahkan mendukung pendapat kelompok Islamis ini. ${ }^{5}$

Penilaian lain lahir juga dari James Piscatori yang menguji tiga model atau performa kaum Islamis di Iran, Turki, dan Palestina. Beberapa catatan menarik terkait penilaian normatif yang menggambarkan pola-pola hubungan kaum Islamis dengan kekuasaan negara, antara lain; 1) Ideologi tidak lagi menjadi rompi pengekang (strait jacket) kalangan Islamis baik dalam bermanuver maupun bertransformasi. Fenomena partai Islam yang dinamis dari Erbakanisme menuju Erdoganisme tidak hanya terjadi di Turki; kaum Islamis Iran pun bergerak di antara pendulum tuntutan demokrasi dan kuasa clerisocracy ala mullah. Sama halnya dengan Hamas yang berubah dari jargon "perempuan adalah tempat mengandung dan pengayom keluarga" bergeser menjadi penyertaan lebih aktif kaum perempuan dalam aktivitas sosial, parlemen, termasuk 
dalam korps angkatan bersenjata negara. 2) Sistem politik bernegara yang dinamis dan modern membuat mereka (kaum Islamis) terus bertransformasi dan akan lebih terbuka pada pragmatisme. 3) Radikalisasi atau moderasi kalangan Islamis juga ditentukan oleh sistem politik negara masing-masing. Faktor ini ikut menentukan apakah mereka akan menjadi lebih demokratis atau justru sebaliknya. ${ }^{6}$

Temuan Piscatori di atas bisa menjadi bahan pemikiran untuk bangsa Indonesia. Bahwa ternyata beberapa studi menunjukkan, perilaku kaum Islamis di dalam sebuah kekuasaan negara bisa lebih mengarah ke moderasi ketimbang radikalisasi. Tergantung bagaimana negara mengelola dan memperlakukan kaum Islamis ini secara adil bukan hanya dalam hal hukum dan politik tetapi juga termasuk segala aspek dalam kehidupan berbangsa dan bernegara. Dalam perkembangannya, Islamisme bisa wujud dalam beberapa faksi tetapi tujuannya tetap sama, yakni mendirikan negara Islam atau setidaknya sistem yang berdasarkan pada ajaran Islam dengan pendekatan tafsir tertentu.

Visi Islamisme di atas biasanya ditempuh melalui aksi-aksi gerakan sosial yang beragam. Aksi damai atau bahkan dengan kekerasan kerap diperlihatkan tergantung oleh sistem nilai yang diyakini para aktor-aktor gerakan Islamis tersebut. Salah satu cara bagaimana mengukur Islamisme adalah dengan mengetahui bagaimana para ideolog Islamis meyakini sistem nilai serta mendefinisikan Islam sebagai ideologi sosial-politik. Di sinilah titik awal munculnya beragam perspektif tentang Islamisme. Salah satu perspektif yang ekstrim adalah, bahwa Islamisme merupakan sebuah gerakan yang menyalahi konsep politik modern. Islamisme sama halnya dengan kaum Fasisme yang telah menjadi musuh terhadap demokrasi dan kebebasan. ${ }^{7}$ Hal inilah kemudian kenapa fenomena Islamisme sering disamakan dengan (ideologi) Marxisme, karena pola pergerakannya yang cendrung memperjuangkan ketidakadilan kelompok tertentu oleh negara. Sama halnya dengan banyaknya orang yang tertarik dengan ideologi Marxis karena Marxisme menawarkan sebuah teori keadilan, bahwa kapitalisme harus dilawan

'Novriantoni Kahar, "Di Bawah Naungan Islamis" dalam https://regional.kompas.com/read /2011/12/31/02475235/di.bawah.naungan.islamis? diakses 10 Juni 2021.

${ }^{7}$ Arun Kundnani, "Islamism and the Roots of Liberal Rage" dalam Race \& Class, Vol. 50, No. 2 (2008), h. 40-68. 
demi terwujudnya keadilan sosial dalam suatu negara. ${ }^{8}$ Hal inilah kemudian fenomena Islamisme ini banyak menuai simpati oleh banyak kalangan khsusnya kaum urban sufisme, yakni mereka haus dengan siraman-siraman spiritual. Kaum Islamis menawarkan solusi kebangsaan dengan menyebut syariat sebagai solusi dan tawarantawaran populis lainnya. Pertanyaannya kenapa kemudian Islamisme dibenci oleh sebagian kalangan karena Islamisme ini terkesan kurang menghormati perbedaan (pluralism). Hal ini bisa dilihat bagaimana mereka memperjuangkan formalisasi syariat. Oleh sebagian masyarakat Muslim maupun non-Muslim, syariat seharusnya jangan dipaksakan masuk dalam ruang-ruang publik seperti itu, seperti peraturan daerah (Perda) yang berbau syariat.

Dalam konteks Indonesia, Islamisme hadir dalam bentuk partai-partai politik dan organisasi Islam bercorak Islamis atau ideologis. Era reformasi telah secara terbuka membuka jalan yang lebar dan secara terbuka untuk menyuarakan syariat Islam baik melalui perjuangan politik parlemen utamanya melalui partai-partai yang berideologi Islam maupun di luar parlemen, seperti Komite Penegakan dan Penerpan Syariat Islam (KPPSI), Wahdah Islamiyah, Hizbu Tahrir Indonesia serta ormas-ormas Islam lainnya. Bagi mereka, Islam adalah ajaran yang sempurna dan akan selalu menawarkan solusi atas masalah umat dan bangsa. Demokrasi yang selama ini diagung-agungkan oleh Barat dinilai gagal mensejahterakan tatanan sosial-politik penduduk dunia. Pada akhirnya kaum Islamis kerap memakai jargon "syariat Islam adalah solusi" atas berbagai masalah sosial-politik di dunia.

Dari sinilah kemudian muncul gerakan revivalisme Islam yang secara ideologis hampir sama dan beririsan dengan Islamisme. Islamic revivalism atau revivalisme Islam adalah fenomena gerakan kebangkitan Islam dengan cara atau gerakan yang dipercaya sebagai satu-satunya jalan keluar dari krisis menuju kejayaan Islam. Pada sisi yang lain revivalisme Islam juga dikonsepsikan sebagai gerakan pembebasan dan pencerahan. Chouieri menyatakan bahwa munculnya revivalisme Islam dilatarbelakangi oleh kemerosotan moral, sosial dan politik umat Islam. ${ }^{9}$ Kembali kepada ajaran Islam yang murni menuju kebangkitan umat menjadi jargon gerakan revivalisme Islam ini. Oleh

\footnotetext{
${ }^{8}$ Peter Baehr, "Marxism and Islamism: Intellectual Conformity In Aron's Time and Our Own" dalam Journal Of Classical Sociology, Vol. 11, No. 2 (2011), h. 173-190.

${ }^{9}$ Youssef M. Choueiri, Islamic Fundamentalism (Boston, Massachusetts: Twayne Publishers, 1990), h. $21-24$.
} 
Hanan, bahwa di antara penyebab kemunduran Islam itu antara lain: 1) Kesalahpahaman umat Islam terhadap agamanya sendiri, dan agar dapat maju umat harus kembali kepada ajaran Islam yang murni. 2) Kemunduran Islam di satu sisi disebabkan oleh imperialisme Barat, dan disisi lain disebabkan oleh pemerintahan yang diktator di kawasan Islam itu sendiri. Sebagai solusi untuk melawan imperialisme tersebut tidak ada jalan lain selain melawan, melakukan reformasi politik dan sains Barat modern harus dikuasai. ${ }^{10}$ Salah satu karakteristik gerakan revivalis Islam adalah adanya keinginan kembali kepada Islam yang asli, memurnikan Islam dari tradisi lokal serta pengaruh budaya asing. Pendapat lain juga mengatakan bahwa munculnya berbagai orientasi ideologi revivalis Islam dipengaruhi oleh adanya perbedaan atas penafsiran terhadap Al-Qur'an, Sunnah dan sejarah Islam awal.

Secara umum, gerakan revivalisme Islam mempunyai kesamaan kerangka ideologis; 1) Konsep din wa dawlah -hubungan agama dan negara- bahwa Islam tidak mengenal sekularisme. 2) Universalisme Islam, bahwa Islam adalah agama yang sempurna yang mengajarkan hampir semua sisi kehidupan manusia. 3) Dasar nalar beragama, bahwa Alquran dan Hadits adalah sumber utama jika menemukan masalah. 4) Penegakan syariat Islam, bahwa tugas umat Islam adalah untuk menegakkan kedaulatan Tuhan dengan menjadikan syariat sebagai undang-undang tertinggi. Keempat kerangka ideologis tersebut biasanya ditopang semangat jihad dengan bebagai karakteristiknya.

Di Indonesia sendiri, geliat gerakan Islam terlihat di akhir dekade 1980-an ketika Orde Baru terus-menerus membatasi bahkan 'melarang' gerakan organisasi Islam dengan cara-cara represif. Perkembangan revivalisme Islam baru terlihat terangterangan pada awal reformasi 1998. Geliat gerakan mereka terlihat, baik dalam ranah politik maupun sosial kemasyarakatan yang secara terang-terangan dan militan serta radikal dengan beragam variannya. Fenomena revivalisme Islam sendiri muncul karena dua hal, yaitu; 1) Sebagai upaya koreksi umat Islam atas sejarahnya sendiri yang selalu mengingat 'romantisme' masa lalu peradaban Islam yang cemerlang. Padahal, ternyata tidak mampu berhadapan dengan peradaban modern. 2) Revivalisme Islam dapat dipahami sebagai respon atas arus modernisasi agar nilai-nilai modernisasi itu tidak h. 21.

${ }^{10}$ Djayadi Hanan, Grakan Pelajar Islam: Di Bawah Bayang-Bayang Negara (Yogyakarta: UII Press, 2006). 
bertentangan dengan nilai-nilai Islam. Kedua hal inilah kemudian menjadi cikal bakal munculnya kompromi dalam perdebatan-perdebatan serius mengenai hubungan Islam dan negara serta gerakan modernisme (pembaruan) dalam Islam di Indonesia sekarang ini.

Secara umum bisa dikatakan bahwa gerakan-gerakan tersebut yang tumbuh di Indonesia termasuk fenomena Islamisme ternyata tidak berakar dari budaya asli Indonesia, tetapi berasal dari proses transmisi gerakan revivalisme Islam di Timur Tengah ke Indonesia, yang terjadi dari sekitar tahun 1980-an sampai 2002-an. Transmisi gerakan tersebut biasa disebut dengan transmisi ideologi trans-nasional, seperti gerakan Ikhwanul Muslimin, Hizbut Tahrir, dan beberapa gerakan Salafi lainnya. Transmisi gerakan dari Timur Tengah ini setidaknya memberi andil dalam aktivisme Islam khususnya di Indonesia. Meskipun Agama secara ideologis tidak menjadi penyebab utama Islamisme kontemporer menyebar di seluruh dunia, akan tetapi ini juga bagian dari efek revivalisme. Revivalisme Islam menjadi isu utama yang menggerakkan sebagian besar umat Muslim untuk membangun kesadaran perlawanan dan perjuangan secara politik di tengah keterpurukan dan ketertinggalan umat.

Krisis yang melanda komunitas Muslim memacu semangat kelompok lain dari masyarakat Islam untuk melakukan purifikasi dengan tujuan mengembalikan umat Islam kepada Islam otentik atau murni dengan cara islah (reformasi) dan tajdid (revivalisme), antara lain dengan merujuk kepada potret Muslim generasi pertama (salaf al-salih). Dengan alasan ini, gerakan ini dikenal sebagai gerakan Salafi (Salfisme atau Salafiyah). Banyak cara digunakan untuk menunjukkan gerakan ini, mulai dari gerakan damai sampai yang bersikap bermusuhan, radikal dan dengan cara kekerasan. Muslim lain dianggap telah menyimpang dari Islam murni yang menjadi target gerakan ini. Gerakan Wahabi yang mendapatkan momentumnya di akhir abad 18 di Saudi Arabia dan gerakan Padri di Sumatra Barat adalah contoh gerakan ini. ${ }^{11}$ Secara ideologis kelihatan bahwa gerakan-gerakan Islam di atas mempunyai kecenderungan ke pola-pola Islamisme. Sulit untuk memberi distingsi yang jelas bagaimana mengkategorisasikan Islamisme ini dalam satu wajah tunggal melainkan kelihatan jamak. Islamisme menjadi kategorisasi umum untuk melihat Islam dalam kerangka gerakan (ideologis) politik.

${ }^{11}$ Masdar Hilmy, Loc.Cit. 
Selanjutnya post-Islamisme menjadi gerakan alternatif bagi aktivis (politik) Islam untuk mengembalikan kejayaan Islam sebagai paradigma baru dalam gerakan politiknya.

\section{Menuju Post-Islamisme}

Aktivisme politik Islam menjadi semakin beragam seiring dengan perkembangan zaman dan realitas politik yang semakin modern. Hal ini kemudian berlanjut kepada isu-isu yang lebih aktual dan kekinian yang membuat peran politik Islam semakin tertantang dalam merespon isu-isu tersebut. Isu tentang agama dan politik tidak lagi menjadi indikator utama dalam melihat aktivisme Islam saat ini, melainkan isu-isu tentang budaya, ekonomi, pendidikan, kesehatan dan isu-isu aktual lainnya menjadi bagian sekaligus keharusan untuk direspon. Hal ini menjadi penting ketika kaum Islamis ini mau eksis dan tetap menuai simpatik dari masyarakat baik Muslim maupun kalangan non-Muslim. Di sinilah awal Islamisme ini bergeser ke arah yang lebih moderat dan mampu beradaptasi dengan realitas politik yang ada. Arah postIslamisme pun menjadi pilihan pola pergerakan kaum Islam politik di tengah realitas politik yang menuntut mereka "patuh" dengan keadaan dan keharusan membuka diri. Kelompok-kelompok Islamis yang punya latar belakang trans-nasional ideologis kelihatan bergeser ke arah politik yang lebih santun dan berkompromi dengan negara, meski dalam hal-hal tertentu masih tetap mempertahankan visi ideologis utama mereka. Fenomena pergeseran identitas ini setidaknya dipengaruhi oleh iklim politik di mana mereka ada.

Dalam konteks Indonesia bisa dilihat bagaimana partai-partai Islam mulai terbuka. Hizbu Tahrir Indonesia (HTI) sebelum dibubarkan juga mencoba tetap menggunakan Pancasila tertuang dalam AD/ART-nya sebagai azasnya. Ormas-ormas Islam lainnya seperti Wahda Islamiyah mencoba berkompromi dengan tetap eksis dan terbuka dalam setiap kontestasi politik. Secara khusus Wahdah Islamiyah ini melakukan ekspansi organiasasi dengan membuka lembaga-lembaga pendidikan dan ekonomi agar tetap eksis dan diminati umat. Formalisasi syariat yang dilakukan oleh ormas-ormas tertentu seperti KPPSI di Sulawesi Selatan kelihatan mati suri hanya karena kurang begitu diterima oleh masyarakat selain konsepnya yang tidak jelas. Partai Islam seperti 
PKS misalnya yang kemudian mendeklarasikan diriya sebagai partai terbuka ${ }^{12}$ adalah salah satu bentuk pergeseran dari Islamisme ke post-Islamisme. Partai-partai Islam seperti PPP dan PBB misalnya yang beberapa kali pemilihan umum menuai suara jauh selisishnya dari partai "sekuler" lainnya salah satu penyebabnya adalah karena masih belum bisa beradaptasi dengan realitas politik modern yang dituntut untuk lebih terbuka. Maka jangan heran kalau misalnya partai-partai seperti PKB dan PAN termasuk Partai Gelora (pecahan PKS) akan jauh lebih eksis dengan partai-partai Islam lainnya dikarenakan mereka lebih dahulu bergerak menuju partai modern.

Fenomena partai-partai Islam tersebut menjadi bagian dari pola pergeseran dari Islamisme ke post-Islamisme. Fenomena tersebut oleh Asef Bayat adalah indikasi kuat munculnya gejala post-Islamisme dalam gerakan Islam di Indonesia. Tidak dapat dipungkiri, ini merupakan implikasi globalisasi dan cepatnya akses informasi yang menyebabkan hubungan antar-gerakan Islam pada skala global semakin cepat. Artinya, peluang menguatnya gerakan post-Islamisme juga cukup kuat di Indonesia. Di antara ciri utama gerakan post-Islamisme antara lain lebih terbuka, realistis terhadap situasi politik, serta kecenderungan untuk berkompromi dengan kekuasaan negara atau sistem politik yang ada. Oleh Asep Bayat, post-Islamisme sama sekali tidak secular apalagi anti Islam yang terkesan memonopoli kebenaran agama.

Post-Islamisme merupakan bagian dari upaya sadar untuk membangun konsep rasionalitas dan modalitas strategis untuk membatasi gerakan Islamisme khususnya di area sosial, politik dan intelektual. Lebih lanjut Bayat mengatakan bahwa perjuangan post-Islamisme adalah untuk mensinergikan Islam dengan pilihan dan kebebasan individu, demokrasi dan modernitas untuk mencapai fase "modernitas alternatif". ${ }^{13}$ Ciriciri umum post-Islamisme di mana-mana kelihatan sama, seperti lebih toleran dan kecenderungan berkompromi dengan pemerintah serta lebih pragmatis dalam merespon program-program pemerintah dan sikap toleran terhadap kelompok-kelompok yang

${ }^{12}$ Presiden PKS, Sohibul Iman, pada saat deklarasi PKS sempat menyatakan bahwa saat ini kita berada di era post-Islamisme sebagai sesuatu yang hatus diterima sekaligus pengakuan. Pertama, pengakuan bahwa zaman perjuangan negara Islam sudah lewat. Kedua, pengakuan bahwa Islamisme sebagai ideologi sudah buntu dan ketinggalan zaman, Ketiga, bahwa symbol-simbol Islamis dalam partai-partai islam tidak lagi menjadi jaminan partai tersebut sebagai partai Islam, Keempat, Syariah sebagai isu utama tidak lagi bisa menjadi solusi atau jualan politik dalam memecahkan persoalan kebangsaan saat ini. Oleh karena itu dibutuhkan terobosan-terobosan baru dalam melihat isu-isu kebangsaan yang terus berubah. Untuk lebih jelasnya lihat, Muhammad Adrian Gifariadi, "Post-Islamisme: Sebuah Pengantar" dalam https://geotimes.id/opini/postislamisme-sebuah-pengantar/diakses 20 Juni 2021.

${ }^{13}$ Asef Bayat, Pos-Islamisme (Yogyakara, LKIS: 2011), h. 20. 
berbeda. Oleh Noorhaidi Hasan, post-Islamisme adalah sintesis antara Islamisme dan globalisasi. $^{14}$

Gejala globalisasi ini kemudian ikut berpengaruh dalam gerakan Islam dan politik Islam dalam ranah kehidupan bernegara pada masa kontemporer. Oleh Asep Bayat, yang meneliti fenomena politik Islam di Iran dan beberapa negara di Timur Tengah, berhasil menjelaskan bagaimana kemunculan pola-pola baru kebangkitan politik Islam di sana yang juga berpengaruh kebeberapa negara lain termasuk Indonesia. Islam dalam dinamika politik terlihat telah mengalami perubahan signifikan terutama dalam membangun aktivisme dalam tujuan politiknya. Berawal dari Islamisme, Bayat menganalisis bagaimana politik Islam sebelumnya terbangun sebagai sebuah aktivisme yang cenderung penolakan terhadap elit politik khususnya kaum liberal. Inilah yang kemudian Bayat menganggap fenomena post-Islamisme merupakan fenomena kelas menengah konservatif-modernis yang memperjuangkan nilai-nilai substansi syariat (tidak secara simbolik-formalistik) tanpa menafikan peran penting kesejahteraan rakyat seperti yang selama ini digaungkan oleh negara-negara Barat. ${ }^{15}$

Secara konseptual dan aksi, pergeseran dari Islamisme ke post-Islamisme bukanlah bentuk penolakan terhadap Islamisme secara umum, akan tetapi bagian dari sebuah evaluasi aktivisme Islam yang secara realistis harus jujur mengatakan bahwa Islamisme ini dianggap gagal dalam aktivismenya selama ini. Indikator yang bisa dilihat antara lain, bagaimana kaum Islamis selama ini identik dengan teroris, gagal dalam memerintah serta konflik (perang) yang berkepanjangan khususnya di negara-negara Timur Tengah termasuk pola aktivisme Islamis di Indonesia. Oleh karena itu, tesis yang kemudian mencuat adalah agama tidak lagi menjadi isu utama dalam membangun aktivisme politik umat di masa depan. Agama akan terus berkompromi dengan kekuasaan dengan beragam bentuknya. Hal ini penting mengingat bahwa postIslamisme itu ada dalam tradisis akademik, kehidupan sehari-hari kaum Muslim bahkan terdapat dalam budaya-budaya popular. Hal ini menandakan bahwa agama dalam ruang publik akan dimaknai sebagai ruang demokrasi yang homogen, sekuler dan liberal di 
mana agama akan melakukan proses adaptasi makna secara substansial. ${ }^{16}$ Agama akan mengalami reinterpretasi konsep dan makna dalam menyangkut kehidupan sosialpolitik masyarakat.

Kegagalan Islamis selama ini menjadi pelajaran berharga bagi para aktivis politik Islam. Mereka belajar dari kegagalan dari praktik politik Islam di beberapa negara mayoritas Islam, seperti Turki, Mesir dan lain-lain khususnya di negara-negara mayoritas penduduknya Muslim. Dari pengalaman dari negara-negara tersebut kaum Islamis terpaksa akur dengan pemerintah setempat dengan berusaha merubah karakter pergerakannya. Post-Islamis pun begitu disambut oleh para aktivis politik Islam sebagai model politik Islam yang dianggap mampu beradaptasi dengan situasi politik modern. Paling tidak mereka hanya mempertahankan pola Islamis yang sifatnya formalistiksimbolistik seperti pakaian dan merespon isu-isu populis di tengah umat, seperti aksi bela Islam, Palestina dan lain-lain sebagai bentuk ekspresi keimanan dan solidaritas bersama. Islamisme bagi kaum Islamis menganggap bahwa demokrasi bukanlah tujuan itu sendiri. Kaum Islamis yang menerima demokrasi dianggap sekedar mempraktikkan "one man, one vote, one time", yang meyindir motif tersembunyi mereka yang akan memberangus demokrasi dan menggantinya dengan sistem teokrasi jika menang pemilu. $^{17}$

Fenomena post-Islamisme ini setidaknya menjadi kritik atas maraknya aksi-aksi politik Islam selama ini yang hanya memanfaatkan agama sebagai alat perjuangan dalam mendapatkan kekuasaan oleh kaum Islamis. Kaum Islamis atau kaum Islamisme memberi panggung bagi kekuatan-kekuatan politik Islam untuk membangun koalisi semu yang pada akhirnya agama menjadi tumbal. Elit-elit Islamis setidaknya mendapatkan hasil dari perjuangan tersebut untuk meraup keuntungan kelompoknya bahkan dirinya sendiri. Hal ini terjadi karena ketidakmampuan para aktivis Islam ini membangun konsep yang matang dalam membangun relasi antara Islam dan realitas sosial-politik kekinian. Mereka hanya terjebak pada politik kepentingan yang pragmatis dan krisis konsep.

\footnotetext{
${ }^{16}$ Bani Syarif Maula, "Post-Islamisme dan Gerakan Politik Islam dalam Sistem Demokrasi Di Indonesia" dalam Al-Daulab: Jurnal Hukum dan Perundangan Islam, Vol. 9, No. (2019), h. 90-116.

${ }^{17}$ Greg Faely, "Kata Pengantar" dalam Burhanuddin Muhtadi, Dilema PKS: Suara dan Syariah (Jakarta: PKG, 2012), h. xvi.
} 


\section{Penutup}

Secara politik, arah post-Islamisme telah berimplikasi dalam aksi politik Islam dewasa ini. Hal ini bisa terlihat bagaimana pola pergerakan politik Islam yang sudah mulai bergeser ke pola aksi-aksi politik Islam yang lebih terbuka, demokratis yang menjunjung nilai-nilai kebebasan. Fenomena ini menjadi fenomena umum ketika dalam kondisi tertentu menuntut adanya proses adaptasi dan menyesuaikan diri dengan keadaan yang ada. Pergeseran isu yang setiap saat berubah menuntut pergeseran paradigma gerakan. Islamisme menuju post-Islamisme merupakan satu kondisi di mana paradigma gerakan (politik) Islam dituntut mampu merespon realitas politik agar tetap eksis dan diminati oleh publik. Globalisasi dan arus gelombang demokrasi dunia seakan tidak terhindarkan seiring dengan sistem politik modern, di mana Islam berada dalam posisi sentral di dalamnya. Peran sentral inilah yang kemudian berusaha ditangkap oleh sebagian aktivis (politik) Islam untuk tetap cerdas dalam melihat fenomena politik tersebut agar tidak ketinggalan di antara gelombang aktivisme politik disekitar mereka. Fenomena post-Islamisme ini menjadi titik temu atau setidaknya titik estafet dari Islamisme ke post-Islamisme menuju paradigma baru gerakan Islam saat ini. Titik temu itu bisa dalam bentuk kemampuan merespon isu-isu baru seperti, kemiskinan, gender dan feminisme, pendidikan dan lain-lain di mana aktivis Islamis sebelumnya tidak mampu merespon isu-isu aktual tersebut.

\section{DAFTAR PUSTAKA}

Azra, Azyumardi. Pergolakan Politik Islam: dari Fundamentalisme, Modernisme, hingga Post-Modernisme. Jakarta: Paramadina, 1996.

Baehr, Peter. "Marxism and Islamism: Intellectual Conformity In Aron's Time and Our Own” dalam Journal Of Classical Sociology, Vol. 11, No. 2 (2011), h. 173190.

Bayat, Asef. Pos-Islamisme. Yogyakara, LKIS: 2011.

Choueiri, Youssef M. Islamic Fundamentalism. Boston, Massachusetts: Twayne Publishers, 1990.

Faely, Greg. "Kata Pengantar" dalam Burhanuddin Muhtadi. Dilema PKS: Suara dan Syariah. Jakarta: PKG, 2012. 
Hanan, Djayadi. Grakan Pelajar Islam: Di Bawah Bayang-Bayang Negara. Yogyakarta: UII Press, 2006.

Hasan, Noorhaidi. Islam Politik di Dunia Kontemporer: Konsep, Genealogi dan Teori. Yogyakarta: SUKA Press, 2012.

Hilmy, Masdar. Teologi Perlawanan: Islamisme dan Diskursus di Indonesia Pasca Orde Baru. Yogyakarta: Kanisisus, 2009.

Kundnani, Arun. "Islamism and the Roots of Liberal Rage" dalam Race \& Class, Vol. 50, No. 2 (2008), h. 40-68.

Maarif, Ahmad Syafii. Islam dan Politik: Teori Belah Bambu Masa Demokrasi Terpimpin (1959-1965). Jakarta: Gema Insani Press, 1996.

Maula, Bani Syarif. "Post-Islamisme dan Gerakan Politik Islam dalam Sistem Demokrasi Di Indonesia" dalam Al-Daulah: Jurnal Hukum dan Perundangan Islam, Vol. 9, No. (2019), h. 90-116.

\section{Internet}

Gifariadi, Muhammad Adrian. "Post-Islamisme: Sebuah Pengantar" dalam https://geotimes.id/opini/post-islamisme-sebuah-pengantar/diakses 20 Juni 2021.

Kahar, Novriantoni. "Di Bawah Naungan Islamis" dalam https://regional.kompas.com /read/2011/12/31/02475235/di.bawah.naungan.islamis? diakses 10 Juni 2021. 